ORIGINAL ARTICLE

\title{
Genetic differentiation in Pyrenophora teres f. teres populations from Syria and Tunisia as assessed by AFLP markers
}

\author{
A. Bouajila ${ }^{1}$, N. Zoghlami ${ }^{1}$, S. Murad ${ }^{2}$, M. Baum ${ }^{2}$, A. Ghorbel ${ }^{1}$ and K. Nazari ${ }^{2}$ \\ 1 Centre de Biotechnologie de Borj-Cédria, Hammam-Lif, Tunisia \\ 2 International Center for Agricultural Research in the Dry Areas (ICARDA), Aleppo, Syria
}

Significance and Impact of the study: The study represents a comparative analysis of the genetic diversity in $P$. teres isolates from two countries spanning two continents and also shows that several distinct $P$. teres genotypes may be found in a given environment. The implications of these findings for Pyrenophora teres f. teres evolutionary potential and net blotch-resistance breeding in Syria and Tunisia were also discussed.

\section{Keywords}

AFLP, Barley, genetic diversity, net blotch,

Pyrenophora teres $\mathrm{f}$. teres, Syria, Tunisia.

\section{Correspondence}

Aida Bouajila, CBBC- Biotechnology Center, Centre de Biotechnologie de Borj-Cédria, BP 901, Hammam-Lif 2050, Tunisia.

E-mail: y.aida@yahoo.fr

2012/0686: received 16 April 2012, revised 10 October 2012 and accepted 14 October 2012

doi:10.1111/lam.12029

\begin{abstract}
To investigate the level of genetic differentiation and diversity among Pyrenophora teres isolate populations originating from different agro-ecological areas of Syria and Tunisia and to determine the potential of AFLP profiling in genotyping Pyrenophora teres $\mathrm{f}$. teres. In this study, AFLP markers have been employed to identify patterns of population structure in 20 Pyrenophora teres $\mathrm{f}$. teres populations from Syria and Tunisia. Ninety-four isolates were studied by the use of a protocol that involved stringent PCR amplification of fragments derived from digestion of genomic DNA with restriction enzymes EcoRI and MesI. Based on 401 amplified polymorphic DNA markers (AFLP), variance analyses indicated that most of the variation was partitioned within rather than between populations. Genotypic diversity (GD) was high for populations from Rihane, local landraces and different agro-ecological zones (GD =0.75-0.86). There was high genetic differentiation among pathogen populations from different host populations in Syria $\left(G_{\mathrm{st}}=0 \cdot 31\right.$, ht $\left.=0 \cdot 190\right)$ and Tunisia $\left(G_{\mathrm{st}}=0 \cdot 39\right.$, ht $\left.=0 \cdot 263\right)$, which may be partly explained by the low gene flow around the areas sampled. A phenetic tree revealed three groups with high bootstrap values $(55,68,76)$ and reflected the grouping of isolates based on host, or agro-ecological areas. AFLP profiling is an effective method for typing the genetically diverse pathogen Pyrenophora teres f. teres.
\end{abstract}

\section{Introduction}

Pyrenophora teres Drechs. [anamorph: Drechslera teres (Sacc.) Shoemaker], is a haploid ascomycete that causes net blotch in barley (Smedegaard-Petersen 1971). This persistent disease is common in all barley-growing regions of the world and occurs typically in cool and humid areas. However, it is a serious disease in the dry areas of North Africa, the Middle East and Australia, and may cause up to $40 \%$ loss in grain yield (Hovmoller et al. 2000; Jayasena 2007; Jebbouj and El Yousfi 2010) in susceptible barley cultivars under epidemic conditions (McLean et al. 2009). Two forms of the disease, the net form (P. teres $f$. teres) and the spot form ( $P$. teres f. maculata), were described based on the symptoms in barley (SmedegaardPetersen 1971; McLean et al. 2009). The net form (P. teres f. teres) is more common in North Africa and the Middle East (Harrabi and Kamel 1990; Arabi et al. 2003). 
Croissant fertile and North Africa are primary centres of barley diversity; however, a few improved varieties are currently replacing a wide range of genetically heterogeneous barley landraces across the region. Some of these varieties, for example Rihane, are susceptible to net blotch, and high infection levels have been observed across the region (Yahyaoui 2004). Reduction in yield due to barley net blotch can be as high as $40 \%$, and the disease is currently one of the major constraints to barley production in Syria and Tunisia (Yahyaoui 2004). This can be attributed to the increasingly intensive production, large monocultures of a few varieties and the environmental conditions that are conducive for disease development (Yahyaoui 2004). Resistant barley cultivars could potentially form the basis of sustainable management strategies for net blotch; however, knowledge of $P$. teres population genetics is needed to understand disease epidemiology, and to effectively breed and use resistant cultivars (McDonald and Linde 2002; McLean et al. 2009).

Pyrenophora teres is known for its high level of pathogenic variation in several countries (Afanasenko and Levitin 1979; Tekauz 1990; Steffenson and Webster 1992; Gupta and Loughman 2001; Cromey and Parkes 2003; Wu et al. 2003; Serenius 2006; Grewal et al. 2008; Silvar et al. 2009), including Syria and Tunisia (Harrabi and Kamel 1990; Arabi et al. 2003). Studies of P. teres populations using colony colour, isozymes, restriction fragment length polymorphism (RFLP), amplified fragment length polymorphism (AFLP) and simple sequence repeats (SSR) revealed high genetic diversity within field populations of the pathogen (Rau et al. 2003, 2005; Wu et al. 2003; Serenius 2006; Keiper et al. 2007).

Information on the dispersal (gene flow) and mode of reproduction of $P$. teres could influence current management strategies for barley net blotch in Syria and Tunisia. AFLP markers are well suited for studies that focus on the role of selectively neutral evolutionary processes such as mating system, genetic drift and gene flow (McDonald and Linde 2002). A more complete understanding of the genetic structure of P. teres f. teres populations in Syria and Tunisia necessitates hierarchical sampling of a relatively large number of isolates on different geographical and spatial scales (Wu et al. 2003).

Genetic differentiation of geographically separated pathogen populations has important implications for the identification and deployment of disease resistance genes. Barley is cultivated in Syria and Tunisia in widely varying agro-ecological zones ranging from subhumid to semiarid, and one hypothesis is that P. teres f. teres populations in these areas are genetically differentiated. The objectives of this study were, to (i) characterize the amount and distribution of genetic variation within and among populations of $P$. teres $\mathrm{f}$. teres sampled in different barley-growing areas of Syria and Tunisia and (ii) use this information to infer the role of different evolutionary forces on the pathogen population in the two countries.

\section{Results}

\section{AFLP analysis}

Combined analysis of AFLP data. A total of 401 discernible and polymorphic AFLP bands were generated with six primer combinations selected across the 94 isolates of 20 Syrian and Tunisian populations of Pyrenophora teres f. teres (Table 2). Primers varied in their ability to detect variation at both within and between populations. The within-populations $H_{\mathrm{o}}$ varied from 0.127 for E11XM50 primer to $0 \cdot 195$ for E11XM47 primer (Table 2).

On average over all primers, the Pyrenophora teres population from Attayet (Siliana, Tunisia) was the most diverse based on several indices (Table 4). While the level of within-population genetic diversity was lower among the samples of population 5 (mean $H_{\mathrm{o}}=0 \cdot 104$ ). Even the genetic diversity between Syrian populations ranged from $0 \cdot 128$ to $0 \cdot 220$ (Tables 1 and 4 ).

Genotypic diversity ranged from 0.75 (population 3, population 7 , population 8 , population 14 , population 15) to a maximum of 0.86 that was recorded at seven of the twenty sites surveyed, indicating that at these sites, every strain represented a distinct genotype.

The variance components of within and between populations detected with AMOVA were 72.76 and $27.24 \%$ of the total variance, respectively, which were both significant at $P<0.001$ (Table 3). This was in approximate agreement with results derived from $H_{\mathrm{o}}$ index, in which within- and between-population variations were 56.61 and $43.39 \%$, respectively. It seems clear that while most of the variation is partitioned within populations, there is still considerable variation between populations.

Across all 20 populations, the number of polymorphic loci at each population ranged from 63 (population 5) to 239 (population 12) and with a percentage of polymorphic loci $15 \cdot 71-59 \cdot 60 \%$, respectively (Table 4 ). Average gene diversity across Syrian and Tunisian populations ranged from $0 \cdot 104$ (population 5) to $0 \cdot 261$ (population 8) (Table 4).

Touiref (population 5) samples were the least variable based on differences between isolates and Shannon's information index (Tables 1 and 4).

A matrix of pairwise $F_{\text {st }}$ values is presented in Table 5 . Values of $F_{\text {st }}$ ranged from -0.0053 (between populations 16 and 17) to 0.637 (between populations 5 and 15). Genetic differentiation was not significant only between Tunisian populations: Barrage Meleg, Touiref and Hamrounia samples $(-0.021,-0.0031,-0.0053$, respectively) 
Table 1 List of Pyrenophora teres f. teres 'isolates' used on this study collected from Syria and Tunisia

\begin{tabular}{|c|c|c|c|}
\hline Code & Reference/site & $\begin{array}{l}\text { Populations code/collection site(district)/Geographic } \\
\text { position/Rainfall }\end{array}$ & Host/row type/year collection \\
\hline 1 & T1B1/TUN1 & Popl/Testour 1 (Beja) HR, NW & Rihane/6R/2009 \\
\hline 2 & T1D1/TUN2 & Popl/Testour 1 (Beja) HR, NW & Rihane/6R/2009 \\
\hline 3 & T1F1/TUN3 & Popl/Testour 1 (Beja) HR, NW & Rihane/6R/2009 \\
\hline 4 & T1C1/TUN71 & Popl/Testour 1 (Beja) HR, NW & Rihane/6R/2009 \\
\hline 5 & T1C2/TUN72 & Popl/Testour 1 (Beja) HR, NW & Rihane/6R/2009 \\
\hline 6 & T3C1/TUN4 & Pop2/Teboursek 1 (Beja) HR, NW & Rihane/6R/2009 \\
\hline 7 & T3F1/TUN5 & Pop2/Teboursek 1 (Beja) HR, NW & Rihane/6R/2009 \\
\hline 8 & T3H1/TUN6 & Pop2/Teboursek 1 (Beja) HR, NW & Rihane/6R/2009 \\
\hline 9 & T6A1/TUN7 & Pop3/Bahra (Kef) MR, NW & Local barley landrace/6R/2009 \\
\hline 10 & T6E1/TUN8 & Pop3/Bahra (Kef) MR, NW & Local barley landrace/6R/2009 \\
\hline 11 & T6G1/TUN9 & Pop3/Bahra (Kef) MR, NW & Local barley landrace/6R/2009 \\
\hline 12 & T6H1/TUN10 & Pop3/Bahra (Kef) MR, NW & Local barley landrace/6R/2009 \\
\hline 13 & T9A1/TUN11 & Pop4/Barrage Maleg (Kef) MR, NW & Local barley landrace/6R/2009 \\
\hline 14 & T9C1/TUN12 & Pop4/Barrage Maleg (Kef) MR, NW & Local barley landrace/6R/2009 \\
\hline 15 & T9D1/TUN13 & Pop4/Barrage Maleg (Kef) MR, NW & Local barley landrace/6R/2009 \\
\hline 16 & T9E1/TUN14 & Pop4/Barrage Maleg (Kef) MR, NW & Local barley landrace/6R/2009 \\
\hline 17 & T9H1/TUN15 & Pop4/Barrage Maleg (Kef) MR, NW & Local barley landrace/6R/2009 \\
\hline 18 & T14B1/TUN16 & Pop5/Touiref (Kef) MR, NW & Local barley landrace/6R/2009 \\
\hline 19 & T14B2/TUN17 & Pop5/Touiref (Kef) MR, NW & Local barley landrace/6R/2009 \\
\hline 20 & T14G1/TUN18 & Pop5/Touiref (Kef) MR, NW & Local barley landrace/6R/2009 \\
\hline 21 & T15F1/TUN19 & Pop6/Gboulat (Siliana) MR, NW & Local barley landrace/6R/2009 \\
\hline 22 & T15G1/TUN20 & Pop6/Gboulat (Siliana) MR, NW & Local barley landrace/6R/2009 \\
\hline 23 & T15G2/TUN21 & Pop6/Gboulat (Siliana) MR, NW & Local barley landrace/6R/2009 \\
\hline 24 & T15B1/TUN59 & Pop6/Gboulat (Siliana) MR, NW & Local barley landrace/6R/2009 \\
\hline 25 & T15D1/TUN60 & Pop6/Gboulat (Siliana) MR, NW & Local barley landrace/6R/2009 \\
\hline 26 & T15C1/TUN61 & Pop6/Gboulat (Siliana) MR, NW & Local barley landrace/6R/2009 \\
\hline 27 & T16A1/TUN22 & Pop7/Mosrata (Siliana) MR, NW & Rihane/6R/2009 \\
\hline 28 & T16B1/TUN23 & Pop7/Mosrata (Siliana) MR, NW & Rihane/6R/2009 \\
\hline 29 & T16E1/TUN24 & Pop7/Mosrata (Siliana) MR, NW & Rihane/6R/2009 \\
\hline 30 & T16H1/TUN25 & Pop7/Mosrata (Siliana) MR, NW & Rihane/6R/2009 \\
\hline 31 & T17C1/TUN26 & Pop8/Attayet (Siliana) MR, NW & Rihane/6R/2009 \\
\hline 32 & T17E1/TUN27 & Pop8/Attayet (Siliana) MR, NW & Rihane/6R/2009 \\
\hline 33 & T17F3/TUN28 & Pop8/Attayet (Siliana) MR, NW & Rihane/6R/2009 \\
\hline 34 & T17H1/TUN29 & Pop8/Attayet (Siliana) MR, NW & Rihane/6R/2009 \\
\hline 35 & T19A1/TUN30 & Pop9/Sers (Kef) MR, NW & Local barley landrace/6R/2009 \\
\hline 36 & T19B1/TUN31 & Pop9/Sers (Kef) MR, NW & Local barley landrace/6R/2009 \\
\hline 37 & T19E1/TUN32 & Pop9/Sers (Kef) MR, NW & Local barley landrace/6R/2009 \\
\hline 38 & T25A1/TUN33 & PoplO/Sidi Mtir, Bouficha (Sousse) LR, C & Local barley landrace/6R/2009 \\
\hline 39 & T25B2/TUN34 & PoplO/Sidi Mtir, Bouficha (Sousse) LR, C & Local barley landrace/6R/2009 \\
\hline 40 & T25C3/TUN62 & PoplO/Sidi Mtir, Bouficha (Sousse) LR, C & Local barley landrace/6R/2009 \\
\hline 41 & T28G1/TUN35 & Popl 1/Hincha (Sfax) LR, S & Local barley landrace/6R/2009 \\
\hline 42 & T28H1/TUN36 & Popl 1/Hincha (Sfax) LR, S & Local barley landrace/6R/2009 \\
\hline 43 & T28A1/TUN73 & Popl 1/Hincha (Sfax) LR, S & Local barley landrace/6R/2009 \\
\hline 44 & T28D1/TUN74 & Popl 1/Hincha (Sfax) LR, S & Local barley landrace/6R/2009 \\
\hline 45 & T28D2/TUN75 & Popl 1/Hincha (Sfax) LR, S & Local barley landrace/6R/2009 \\
\hline 46 & T28F1/TUN76 & Popl 1/Hincha (Sfax) LR, S & Local barley landrace/6R/2009 \\
\hline 47 & T51E2/TUN37 & Popl2/Bir Mcharga (Zaghouan) MR,NE & Rihane/6R/2009 \\
\hline 48 & T51C2/TUN63 & Popl2/Bir Mcharga (Zaghouan) MR, NE & Rihane/6R/2009 \\
\hline 49 & T51A2/TUN65 & Popl2/Bir Mcharga (Zaghouan) MR, NE & Rihane/6R/2009 \\
\hline 50 & T51F2/TUN66 & Popl2/Bir Mcharga (Zaghouan) MR, NE & Rihane/6R/2009 \\
\hline 51 & T51C1/TUN67 & Popl2/Bir Mcharga (Zaghouan) MR, NE & Rihane/6R/2009 \\
\hline 52 & T51D2//TUN68 & Popl2/Bir Mcharga (Zaghouan) MR, NE & Rihane/6R/2009 \\
\hline 53 & T51H1/TUN69 & Popl2/Bir Mcharga (Zaghouan) MR, NE & Rihane/6R/2009 \\
\hline 54 & T51H2/TUN70 & Popl2/Bir Mcharga (Zaghouan) MR, NE & Rihane/6R/2009 \\
\hline
\end{tabular}


Table 1 (continued)

\begin{tabular}{|c|c|c|c|}
\hline Code & Reference/site & $\begin{array}{l}\text { Populations code/collection site(district)/Geographic } \\
\text { position/Rainfall }\end{array}$ & Host/row type/year collection \\
\hline 55 & T52A1/TUN38 & Popl3/El fahs (Zagouhan) MR, NE & Local barley landrace/6R/2009 \\
\hline 56 & T52B1/TUN39 & Popl3/El fahs (Zagouhan) MR, NE & Local barley landrace/6R/2009 \\
\hline 57 & T52C1/TUN40 & Popl3/El fahs (Zagouhan) MR, NE & Local barley landrace/6R/2009 \\
\hline 58 & T52D1/TUN41 & Popl3/El fahs (Zagouhan) MR, NE & Local barley landrace/6R/2009 \\
\hline 59 & T52D2/TUN42 & Popl3/El fahs (Zagouhan) MR, NE & Local barley landrace/6R/2009 \\
\hline 60 & T52E1/TUN43 & Popl3/El fahs (Zagouhan) MR, NE & Local barley landrace/6R/2009 \\
\hline 61 & T52H2/TUN44 & Popl3/El fahs (Zagouhan) MR, NE & Local barley landrace/6R/2009 \\
\hline 62 & T53B2/TUN45 & Popl4/Saoif (Zagouhan) MR, NE & Rihane/6R/2009 \\
\hline 63 & T53D1/TUN46 & Pop14/Saoif (Zagouhan) MR, NE & Rihane/6R/2009 \\
\hline 64 & T53F2/TUN47 & Pop14/Saoif (Zagouhan) MR, NE & Rihane/6R/2009 \\
\hline 65 & T53G3/TUN48 & Pop14/Saoif (Zagouhan) MR, NE & Rihane/6R/2009 \\
\hline 66 & T55A3/TUN49 & Pop15/Mograne (Zagouhan) MR, NE & Rihane/6R/2009 \\
\hline 67 & T55C2/TUN50 & Pop15/Mograne (Zagouhan) MR, NE & Rihane/6R/2009 \\
\hline 68 & T55D1/TUN51 & Pop15/Mograne (Zagouhan) MR, NE & Rihane/6R/2009 \\
\hline 69 & T55G1/TUN52 & Pop15/Mograne (Zagouhan) MR, NE & Rihane/6R/2009 \\
\hline 70 & T57B1/TUN53 & Pop16/Souidia (Bizerte) HR, NN & Rihane/6R/2009 \\
\hline 71 & T57B2/TUN54 & Pop16/Souidia (Bizerte) HR, NN & Rihane/6R/2009 \\
\hline 72 & T57C1/TUN55 & Pop16/Souidia (Bizerte) HR, NN & Rihane/6R/2009 \\
\hline 73 & T57A1/TUN77 & Pop16/Souidia (Bizerte) HR, NN & Rihane/6R/2009 \\
\hline 74 & T57H1/TUN78 & Pop16/Souidia (Bizerte) HR, NN & Rihane/6R/2009 \\
\hline 75 & T59B1/TUN56 & Pop17/Hamrounia (Bizerte) HR,NN & Rihane/6R/2009 \\
\hline 76 & T59H1/TUN57 & Pop17/Hamrounia (Bizerte) HR,NN & Rihane/6R/2009 \\
\hline 77 & T59E1/TUN64 & Pop17/Hamrounia (Bizerte) HR,NN & Rihane/6R/2009 \\
\hline 78 & T59G1/TUN79 & Pop17/Hamrounia (Bizerte) HR, NN & Rihane/6R/2009 \\
\hline 79 & S1/ICAPtr 1 & Pop18/Al Bab (ALEPPO) MR, N & Local barley landrace/2R/1998 \\
\hline 80 & S2/ICAPtr2 & Pop18/Al Bab (ALEPPO) MR, N & Local barley landrace/2R/1998 \\
\hline 81 & S7/ICAPtr 5 & Pop18/Al Bab (ALEPPO) MR, N & Local barley landrace/2R/1998 \\
\hline 82 & S3/ICAPtr3 & Pop19/Mossaf (HAMA) MR, W & Local barley landrace/2R/2003 \\
\hline 83 & S8/ICAPtr6 & Pop19/Souran (HAMA) MR, W & Local barley landrace/2R/2006 \\
\hline 84 & S10/ICAPtr7 & Pop19/Al Gab (HAMA) MR, W & Local barley landrace/2R/2009 \\
\hline 85 & S11/ICAPtr8 & Pop19/Al Gab (HAMA) MR, W & Local barley landrace/2R/2009 \\
\hline 86 & S12/ICAPtr9 & Pop19/Al Gab (HAMA) MR, W & Local barley landrace/2R/2009 \\
\hline 87 & S13/ICAPtr10 & Pop19/Al Gab (HAMA) MR, W & Local barley landrace/2R/2009 \\
\hline 88 & S14/ICAPtr11 & Pop19/Al Gab (HAMA) MR, W & Local barley landrace/2R/2009 \\
\hline 89 & S16/ICAPtr12 & Pop20/ICR-Station (TARTOUS) HR, W & Local barley landrace/?/2007 \\
\hline 90 & S17/ICAPtr13 & Pop20/ICR-Station (TARTOUS) HR, W & Local barley landrace/?/2007 \\
\hline 91 & S18/ICAPtr14 & Pop20/ICR-Station (TARTOUS) HR, W & Local barley landrace/?/2007 \\
\hline 92 & S19/ICAPtr15 & Pop20/ICR-Station (TARTOUS) HR, W & Local barley landrace/?/2007 \\
\hline 93 & S21/ICAPtr16 & Pop20/ICR-Station (TARTOUS) HR, W & Local barley landrace/?/2007 \\
\hline 94 & S23/ICAPtr17 & Pop20/ICR-Station (TARTOUS) HR, W & Local barley landrace/?/2007 \\
\hline
\end{tabular}

(Table 5). The rest of values were all significant at $P<0.001$. This indicates that all populations may be considered different from each other, with population 5 being the most different from the others and populations $1,4,9$ and 16 being the most similar. The overall $F_{\text {st }}$ across all the populations was $0 \cdot 27$.

The significant differentiation between populations was also revealed in the clustering analysis (Fig. 1) and reflected in the estimates of gene flow $\left(N_{\mathrm{m}}\right)$ (Table 2).

Values of $N_{\mathrm{m}}$ ranged from a moderate value of 0.84 to a high value of $1 \cdot 18$, averaging $0 \cdot 653$, which indicated that Pyrenophora teres populations tend to differentiate between the twenty studied populations.

The total variation among Pyrenophora teres was further tested based on geographic countries (Syria, Tunisia) (Table 2). Most of the total variation (68.55\%) was identified within Syrian populations, $40 \%$ was identified among Tunisian populations. Although, genetic differentiation was significant between countries ( $F_{\text {st }}$ ranging from $0 \cdot 126$ to $0 \cdot 572$ ), results show that the isolates of $P$. teres are genetically more distinct across a wide geographical area. Moderate gene flow was found in 
Table 2 Genetic diversity identified by six AFLP primers combinations in 94 isolates from Syria and Tunisia

\begin{tabular}{lllll}
\hline AFLP primer combinations & $H_{\mathrm{t}}$ & $H_{\mathrm{s}}$ & $G_{\text {st }}$ & $N_{\mathrm{m}}$ \\
\hline E11XM47 & 0.295 & 0.194 & 0.404 & 0.985 \\
E11XM50 & 0.218 & 0.127 & 0.340 & 1.180 \\
E17XM47 & 0.320 & 0.172 & 0.441 & 0.866 \\
E17XM50 & 0.262 & 0.147 & 0.399 & 0.845 \\
E15XM47 & 0.296 & 0.169 & 0.371 & 1.085 \\
E15 X M50 & 0.266 & 0.157 & 0.382 & 1.052 \\
TUN pop (17pop, 78 isolates) & 0.263 & 0.158 & 0.398 & 0.756 \\
Syrian pop(3pop, 16 isolates) & 0.190 & 0.130 & 0.314 & 1.092 \\
All populations (20pop, 94 isolates & 0.272 & 0.154 & 0.433 & 0.653 \\
\hline
\end{tabular}

$H_{\mathrm{t}}$, Gene diversity totalled among populations; $H_{\mathrm{s}}$ Gene diversity within populations; $G_{\text {st }}$ Genetic differentiation between populations; $N_{\mathrm{m}}$, Number of migrants.

Table 3 Amova analysis for the Pyrenophora teres f. teres populations using 401 AFLP bands

\begin{tabular}{lccll}
\hline Source of variation & df & $\begin{array}{l}\text { Sum of } \\
\text { squares }\end{array}$ & $\begin{array}{l}\text { Variance } \\
\text { components }\end{array}$ & $\begin{array}{l}\text { Variation } \\
(\%)\end{array}$ \\
\hline Among populations & 19 & 2134.373 & $15 \cdot 290^{* * *}$ & 27.24 \\
Within populations & 74 & 3022.808 & $40 \cdot 848^{* * *}$ & 72.76 \\
Total & 93 & 5157.181 & 56.139 & \\
\hline
\end{tabular}

$* * * P<0.001$.
Tunisian populations $N_{\mathrm{m}}<0 \cdot 756$, while $N_{\mathrm{m}}=1$ in Syrian populations.

Cluster polymorphism. The genetic distance among field populations was estimated using Nei's unbiased measure of genetic distance (Nei 1978).

Cluster analysis based on UPGMA allowed a graphical representation of genetic similarity among 94 isolates from different sampling sites of Syria and Tunisia. Pyrenophora teres populations were grouped onto three main clusters that were genetically very distant from each other with bootstrap 55, 68, 76 (Fig. 1). Bootstrap values were generally high, in 47 cases were the values $>50$ (Fig. 1). There were two main clusters at the linkage distance level of 0.37 that were well supported by bootstrap values of $100 \%$. The first cluster contained two isolates ICAPtr 16 and ICAPtr 17 from Syrian populations Hama and Tartous with bootstrap 76. The second cluster comprised 13 isolates from Aleppo, Hama and Tartous in Syria with only three isolates from two areas of Tunisia namely TUNPtr 59, 60, 76 (Gboulat, Siliana, NW), (Hincha, Sfax, $\mathrm{SE}$ ) (Table 1). The third cluster comprised most of the Tunisian isolates (76 isolates) with only two isolates from Syria (Hama) ICAPtr 12 and 13 (Fig. 1, Table 1).

Conversely, the obtained dendrogram revealed no apparent association between geographical distance or

Table 4 Molecular diversity estimates and its significance for Pyrenophora teres f. teres populations based on all isolates sampled from Syria and Tunisia

\begin{tabular}{|c|c|c|c|c|c|c|}
\hline TUN/Syr pop & $\begin{array}{l}\text { Average of gene } \\
\text { diversity overall loci }\end{array}$ & $\begin{array}{l}\text { Average of pairwise } \\
\text { differences }\end{array}$ & $F_{S T}$ indices & $\begin{array}{l}\text { Number of } \\
\text { polymorphic loci }\end{array}$ & $\begin{array}{l}\% \text { of polymorphic } \\
\text { loci }\end{array}$ & Shannon's index \\
\hline TUN pop 1 & $0.196 \pm 0.119$ & $78.600 \pm 41.064$ & 0.275 & 160 & $39 \cdot 9$ & 0.231 \\
\hline TUN pop 2 & $0.221 \pm 0.165$ & $88.666 \pm 53 \cdot 345$ & 0.284 & 133 & 33.17 & 0.211 \\
\hline TUN pop 3 & $0.225 \pm 0.148$ & $90 \cdot 333 \pm 49 \cdot 725$ & 0.264 & 161 & $40 \cdot 14$ & 0.245 \\
\hline TUN pop 4 & $0.198 \pm 0.120$ & $79 \cdot 400 \pm 41.478$ & 0.274 & 171 & $42 \cdot 64$ & 0.237 \\
\hline TUN pop 6 & $0.234 \pm 0.136$ & $94.000 \pm 47.348$ & 0.238 & 206 & $51 \cdot 37$ & 0.289 \\
\hline TUN pop 7 & $0.258 \pm 0.170$ & $103 \cdot 833157 \cdot 103$ & 0.239 & 189 & $47 \cdot 13$ & 0.283 \\
\hline TUN pop 8 & $0.261 \pm 0.171$ & $104.833 \pm 57.650$ & 0.237 & 195 & $48 \cdot 62$ & 0.287 \\
\hline TUN pop 9 & $0.2391 \pm 0.179$ & $96.000 \pm 57.728$ & $0 \cdot 273$ & 144 & $35 \cdot 91$ & 0.228 \\
\hline TUN pop 10 & $0.22210 \cdot 167$ & $89 \cdot 333 \pm 53 \cdot 744$ & $0 \cdot 283$ & 134 & 33.41 & $0 \cdot 212$ \\
\hline TUN pop 11 & $0.217 \pm 0.126$ & $87 \cdot 333 \pm 44 \cdot 015$ & $0 \cdot 251$ & 199 & $49 \cdot 62$ & 0.272 \\
\hline TUN pop 12 & $0.217 \pm 0.119$ & $87 \cdot 321 \pm 42 \cdot 162$ & $0 \cdot 243$ & 239 & $59 \cdot 60$ & 0.294 \\
\hline TUN pop 14 & $0.143 \pm 0.094$ & $57.666 \pm 31.871$ & 0.323 & 109 & $27 \cdot 18$ & 0.159 \\
\hline TUN pop 15 & $0.139 \pm 0.092$ & $56 \cdot 000 \pm 30 \cdot 960$ & 0.326 & 101 & $25 \cdot 18$ & 0.152 \\
\hline TUN pop 16 & $0.199 \pm 0.121$ & $79.800 \pm 41.685$ & 0.273 & 168 & 41.89 & 0.236 \\
\hline TUN pop 17 & $0.194 \pm 0.127$ & $77.833 \pm 42 \cdot 893$ & 0.286 & 144 & $35 \cdot 91$ & 0.213 \\
\hline Syr pop 18 & $0.128 \pm 0.096$ & $51.333 \pm 31.034$ & 0.345 & 77 & $19 \cdot 20$ & 0.122 \\
\hline Syr pop 19 & $0.143 \pm 0.081$ & $57.428 \pm 28.356$ & 0.308 & 142 & $35 \cdot 41$ & $0 \cdot 186$ \\
\hline Syr pop20 & $0.220 \pm 0.128$ & $88.466 \pm 44.581$ & 0.249 & 197 & $49 \cdot 12$ & 0.273 \\
\hline All populations & $0.227 \pm 0.199$ & $70 \cdot 347 \pm 39 \cdot 857$ & 0.286 & 158 & $39 \cdot 46$ & 0.227 \\
\hline
\end{tabular}

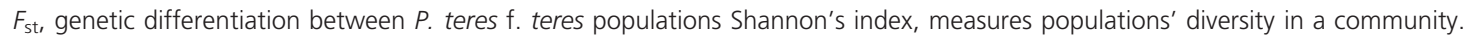




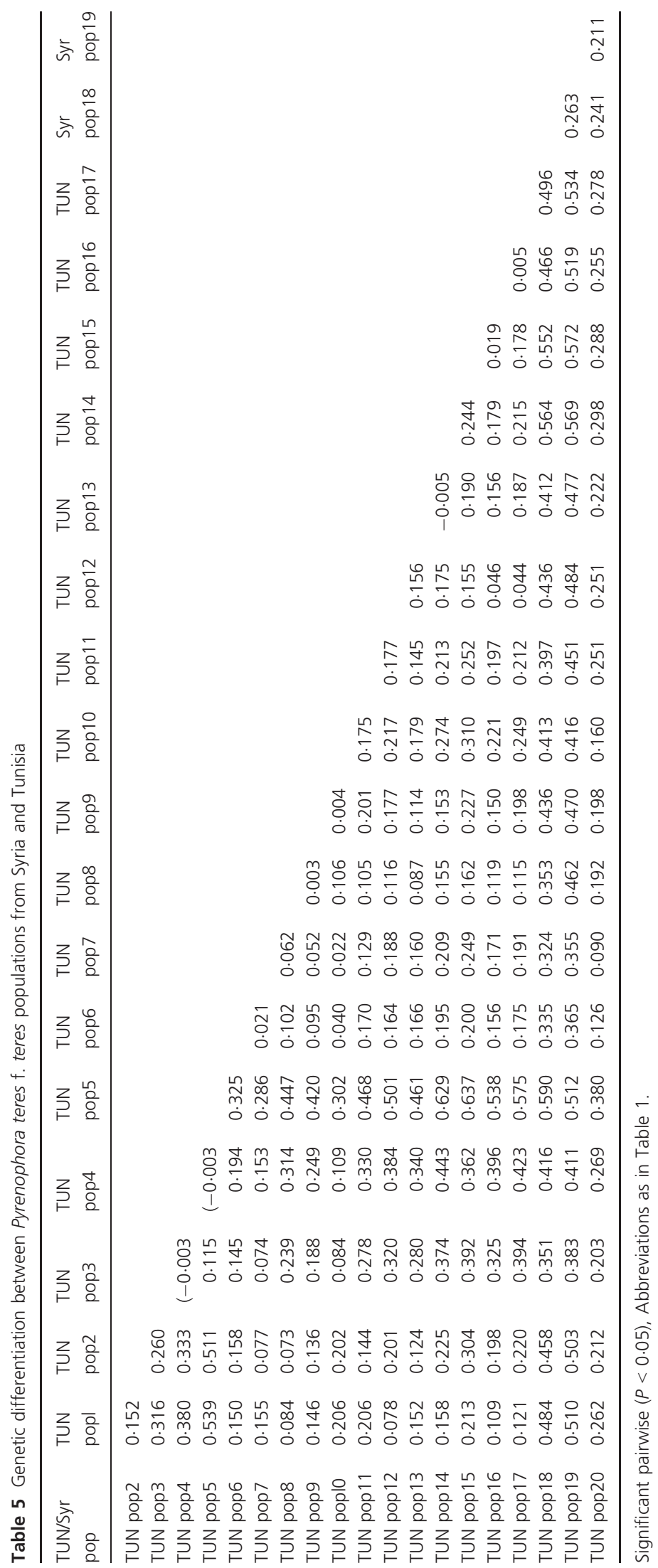


regional affiliation and the genetic distance between the populations. Indeed, $P$. teres $\mathrm{f}$. teres isolates obtained from different sampling sites in the same area or country did not cluster together (Fig. 2). The mean genetic distance of each of the 20 populations from all others ranged from 0.027 to 0.325 . The least genetic distance (0.027) was recorded between populations Bahra (Kef, NW Tunisia) and Barrage Meleg (Kef, NW Tunisia), while populations Touiref (Kef, NW Tunisia) and Hamrounia (Bizerte, NN Tunisia) were the most genetically distant (0.325). The $20 \mathrm{P}$. teres populations were grouped into two main clusters that were genetically very distant from each other. The cluster I was composed only by the Tunisian populations from 14 locations corresponding to different agroecological zones (Béja, Siliana, Kef, Zaghouan, Bizerte, Sousse, Sfax). The cluster II contained, however, apart from region Kef (Northwest Tunisia) that was represented by a three field populations (Bahra, Barrage Meleg and Touiref) and all Syrian populations (Fig. 2). None of the individualized subclusters comprised field populations from a single area, indicating considerable gene flow between regional populations (e.g. populations T8, T11,

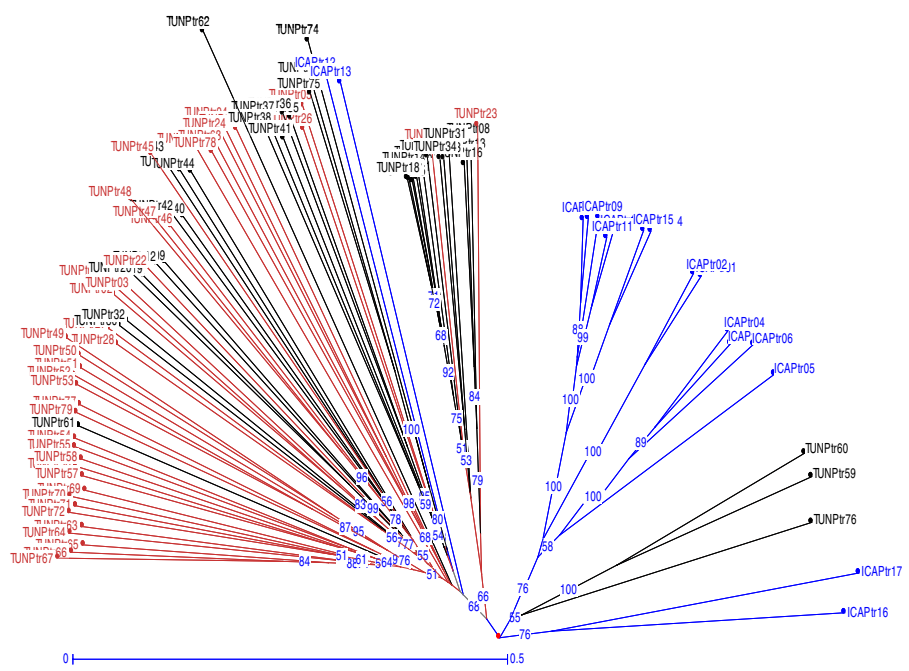

Figure 1 UPGMA phenogram of Pyrenophora teres f. teres based on the AFLP data. Numbers on branches are bootstrap values. The isolates are designated by alphanumerics represent the origin (ICAPtr blue color represent isolates collected from Syria; TUNPtr: represent isolates sampled from Tunisia), followed by the host (the red color, for cv. Rihane and black one for a landrace cultivar).

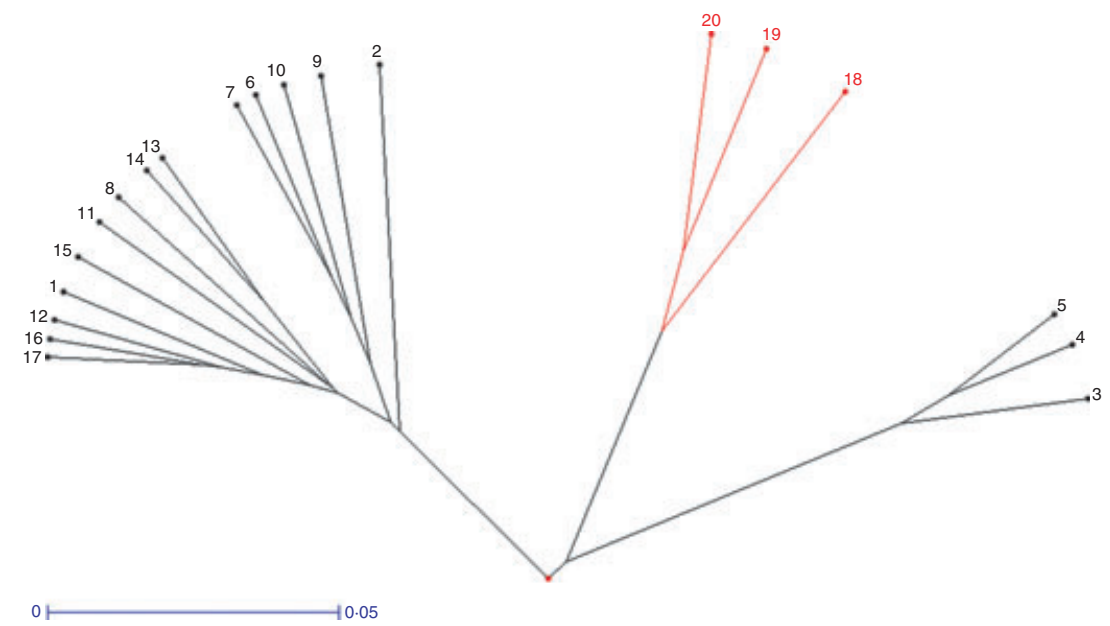

Figure 2 UPGMA dendrogram of twenty Pyrenophora teres $\mathrm{f}$. teres populations from Syria and Tunisia based on the AFLP data. The populations are designated by numerics (see Table 1). From P1 to P20: Tunisian and Syrian net blotch populations were represented on black and red, respectively. Cluster I Tunisian populations 1(P1), 2(P2), 6(P6), 7(P7), 8(P8), 9(P9), 10(P10), 11(P11), 12(P12), 13(P13), 14(P14), 15(P15), 16(P16), and Cluster II Syrian and Tunisian populations: 17(P17), 18(P18), 19(P19), 20(P20), 3(P3), 4(P4), 5(P5). 
T13 and T14; T6, T7, T9 and T10; T15 and T1) (Fig. 2, Table 1).

\section{Discussion}

Croissant fertile and North Africa are primary centres of barley diversity, and many barley growers in Syria and Tunisia still rely on genetically heterogeneous landraces, some of which are derived from the seeds that were transferred from generation to generation (Ceccarelli et al. 1987; Zoghlami et al. 2011). If pathogenicity on barley was acquired by a large number of genetically distinct strains, then $P$. teres populations in Syria and Tunisia have coevolved with many barley genotypes over a long period of time, resulting in a diverse pathogen population. It is, therefore, not surprising that all populations exhibited a high degree of genotype diversity $(0.8)$ within a spatial scale of $1 \mathrm{~m}^{2}$.

In this study, the marker technology has been employed to detect genetic variation and population structure of Pyrenophora teres f. teres from Syria and Tunisia and has once again demonstrated its usefulness in gaining information quickly and usefully in breeding programmes.

AFLP markers, along with appropriate statistical procedures are suitable for genetic variation analyses at both intra- and interpopulation levels (Serenius et al. 2007; Bentata et al. 2011).

The level of genetic diversity at AFLP markers detected here $(H \mathrm{sp}=0 \cdot 276)$ is comparable to or higher than, diversity levels reported for pathogen when using biochemical and molecular markers (Jonsson et al. 2000; Zaki and Al-Masry 2008).

The genetic variation was maintained within rather than between the studied populations (58.33\%) as detected with amova. Similarly, Serenius et al. (2007) found that in Russian P. teres f. teres 20 and $80 \%$ of the total variation was partitioned among and within populations, respectively. Leisova et al. (2005a,b) showed that $98.1 \%$ of genetic variance occurred within local populations and $1.9 \%$ was found among populations. However, Bentata et al. (2011) revealed a high genetic variability between the studied isolates in Morocco. The Syrian and Tunisian isolates were highly variable and contributed $27 \cdot 24 \%$ of the total variation observed among all isolates using AMOVA analysis. AMOVA analysis revealed significant differences among populations and among samples within population $(P<0.001)$ (Table 3$)$.

Conversely, high genetic variability at population level was detected. Indeed, a high number of polymorphic markers was produced by the Tunisian population no. 12 (239 markers) and the Syrian population no. 20 (197 markers), respectively, with a percentage of polymorphic loci 52 and 49\% (Table 4). Also, 87 different haplotypes were identified among the 94 isolates studied. In others words, 87 isolates have specific genotypes, suggesting that there is more genetic recombination, which may have played a major role in genetic diversity of Syrian and Tunisian Pyrenophora teres f. teres. In addition, the high diversity might be either a result of a high mutation rate, large population size or retrotransposons, which can all contribute to diversity in asexually reproducing populations (McDonald and Linde 2002; Taylor et al. 2004).

These findings also indicated significant genetic subdivision of the Syrian and Tunisian $P$. teres populations according to $F_{\mathrm{st}}$ values $\left(F_{\mathrm{st}}=0.27, P<0.001\right)$. The $F_{\mathrm{st}}$ estimate is considered to be more biased than $\Phi_{\mathrm{ST}}$ for the evaluation of differentiation coefficient for dominant marker data and may suggest that the $P$. teres populations analysed are moderately differentiated according to Wright's interpretation of $F_{\text {st }}$ values (Wright 1978).

As Syria is the primary centre of origin of Hordeum species, it can therefore shelter old pathogen populations, where mutation events occurring over a long period of time have increased pathogen population diversity. This was supported by the $F_{\text {st }}$ value (Table 4) that identified Syria to have most of the variation identified elsewhere. High diversity has also been observed in Fusarium graminearum Schwabe [teleomorph (Gibberella zeae) (Schwein.)] in West Asia and Southern Russia, which was suggested to be the origin of $F$. graminearum, whereas the Finnish F. graminearum isolates were significantly less variable (Gagkaeva and Yli-Mattila 2004).

In the present study, genetic differentiation among the 20 field populations (sample size of 3-8 isolates) was high $\left(G_{\mathrm{st}}=0.398\right)$ but dropped to 0.31 when Syrian field populations were grouped together, and increase to 0.40 in Tunisian field populations (Table 2). In fact, cereal pathogen populations are relatively old in Syria (Burdon and Silk 1997; Khan and Tekauz 1982), and were likely established by relatively few isolates. Migration via seed to intra- and interareas in Syria, and therefore the diversity, has remained comparatively high.

A moderate level of genetic differentiation was found between the pathogen population from Tunisia and Syria based on Nei's genetic distances, high $G_{\text {st }}$ values with $N_{\mathrm{m}}=0.653$. Although, evidence for differentiation was found in pairwise comparisons involving populations from all other areas $\left(F_{\mathrm{st}}=0 \cdot 11-0 \cdot 63\right)$, suggesting that the 'geographic populations' in this study are evolving independently and hence may be considered not a part of the same 'genetic population'. The moderate differentiation observed may have resulted from the rather small number of isolates sampled in populations $(8,20)$ although bootstrap tests of significance enabled us to estimate indices of population differentiation with a reasonable degree of 
confidence (Grünwald et al. 2003). This differentiation may indicate local adaptation of $P$. teres to the high rainfall conditions of different areas in Syria and Tunisia compared with the moderate or low rainfall conditions in the more arid regions. Assuming that our AFLP data accurately reflect the differentiation between these populations in Syria and Tunisia, they indicate that the identification and deployment of net blotch-resistant varieties would need to take into consideration these two different regional populations. However, detailed analysis of gene flow between areas using larger sample sizes and codominant markers is warranted to corroborate the moderate population differentiation observed in this study. Knowledge of pathotype distribution will also help determine whether $P$. teres pathotypes in the country are geographically circumscribed (Bouajila et al. 2011).

The most probable explanation for the high genotype diversity, moderate gene flow and high genetic differentiation of the pathogen population in Syria and Tunisia is sexual reproduction and air dispersal of ascospores. Forcibly discharged ascospores become airborne and may serve as primary inoculum over considerable distances (Trail et al., 2002). Wind dispersal of ascospores enables the migration of new genotypes into barley fields and may facilitate the rapid dissemination of virulent mutants across entire areas. Many studies showed the identification of the telemorph and detection of sexual recombination in natural populations of $P$. teres (McLean et al. 2009).

The importance of genetic diversity and the potential consequences associated with narrowing the genetic base of cultivated barley has long been recognized by plant pathologists and plant breeders. The potential for severe net blotch epidemics has increased with the production of modern homogenous, genetically uniform barley varieties with specific genes for resistance to barley net blotch. The high genetic diversity, the high gene flow and the potential for sexual recombination in Syria and Tunisian populations of $P$. teres mean that reliance on major gene resistance is unlikely to be an appropriate breeding strategy (McDonald and Linde 2002).

In conclusion, the existence of genetic variability observed, can be explained by inter-regional and intraregional gene flow between the Syrian and Tunisia isolates. However, the durability of specific resistance genes may be increased by the use of multiline cultivars, by combining ('pyramiding') different resistance genes. Syria includes in Middle East, which is the centre of origin and earliest knowledge of domestication for many cereal crops. Increased knowledge of the population biology of $P$. teres is likely to lead to better management of disease in agricultural ecosystems. Recently, $P$. teres f. teres isolates were differentially pathogenic. CI09214 and CI05401 cultivars were released as the most effective sources of resistance in Syria and Tunisia (Bouajila et al. 2011) and combined (pyramided) into elite varieties and by deploying many cultivars with different resistance genes in space or time.

\section{Materials and methods}

\section{Collection of $P$. teres isolates}

In this study, $94 P$. teres $\mathrm{f}$. teres isolates were sampled from barley-infected leaves from 20 locations (17 populations from Tunisia and three populations from Syria) throughout the major barley-growing areas in Syria and Tunisia (Table 1).

For the Tunisian isolates, leaf samples were collected from naturally infected fields during the 2009 season using the hierarchical sampling method described by McDonald et al. (1999): one field population was sampled at each location, drawing a composite sample from eight circular spots of $1 \mathrm{~m}$ diameter each located along two parallel transects (with four spots per transect). The two transects and the collection sites (spots) along the transects were separated from the adjacent members by $10 \mathrm{~m}$. This field design allowed a total sampling area of $408 \mathrm{~m}^{2}$ $(12 \times 34 \mathrm{~m})$. Ten infected leaves were sampled from different plants or tillers in a circular sweep of each sampling spot. Most collections were made from the northern subhumid to semi-arid region (69 isolates), which is the largest barley-growing area in Tunisia, and the rest from the central (three isolates) and the southern regions (six isolates) of the country.

Sixteen Syrian net blotch infected leaf samples were collected from three locations covering the major barleygrowing areas in the northern subhumid to the semi-arid region in North Western (three isolates), and Western (13 isolates) Syria (Table 1) in springs of 1998, 2003, 2006, 2007 and 2009. Fields were sampled randomly along major roads in the principal barley productions areas in Syria (three populations).

Leaf samples were placed in paper envelopes, air-dried at room temperature for $48 \mathrm{~h}$ and stored at $6^{\circ} \mathrm{C}$ until required.

\section{Single-spore isolation and inoculum production}

Leaves showing typical net blotch symptoms were cut into discs 5-10 $\mathrm{mm}$ in diameter, surface-sterilized in 90\% ethanol for $10 \mathrm{~s}$ and in $1 \% \mathrm{NaCl}$ for $60 \mathrm{~s}$, rinsed twice in sterile deionized water for $1 \mathrm{~min}$ each time, blotted, dried and aseptically transferred to Potato dextrose agar (PDA) plates. The plates were incubated at $20^{\circ} \mathrm{C}$ for several days under alternating cycles of $12 \mathrm{~h}$ of near-ultraviolet (NUV) 
light and $12 \mathrm{~h}$ of darkness. After 3-5 days, single conidia were transferred with a needle, while looking through a microscope, to fresh PDA plates and incubated for 2 weeks to induce growth of mycelia.

\section{DNA extraction}

Approximately $0.05 \mathrm{~g}$ of the freeze-dried fungal tissue was ground into a fine powder in a 2-ml microfuge tube using a mixer-mill. Total DNA from each fungal isolate was extracted using a modified hexadecyltrimethylammonium bromide (CTAB) extraction procedure (Bouajila et al. 2007). Extracted DNA was resuspended in TrisEDTA buffer $\left(10 \mathrm{mmol}^{-1}\right)$ and stored at $-20^{\circ} \mathrm{C}$. DNA concentrations were estimated by spectrophotometry and/ or agarose gel electrophoresis. DNAs were run in a $0.8 \%$ agarose gel to verify the quality and the concentration.

\section{AFLP analysis}

The AFLP procedure was performed with minor modifications according to the protocol of Vos et al. (1995). Approximately 40-ng DNA was digested simultaneously with EcoRI and $\mathrm{MseI}$ at $37^{\circ} \mathrm{C}$ for $4 \mathrm{~h}$. The digested samples were incubated at $70^{\circ} \mathrm{C}$ for $15 \mathrm{~min}$ to inactivate the restriction endonucleases. EcoRI and MseI adapters were ligated to the digested samples at $20^{\circ} \mathrm{C}$ for $4 \mathrm{~h}$. This was performed to generate template DNA for amplification. Pre-amplification was carried out with +1 - primers each carrying one selective nucleotide $(E c o R I+\mathrm{A}$ and MseI + C) in a thermocycler for 30 cycles (94, 56 and $\left.72^{\circ} \mathrm{C} / 30 \mathrm{~s}\right)$. The amplification products were stored at $-20^{\circ} \mathrm{C}$. Selective amplification was carried out with EcoRI +1 and 2 - primers and MseI +3 - primers and $5 \mu \mathrm{l}$ of the diluted PCR products from the pre-amplification. Six primer pair combinations were employed in this study (Table 2). The PCR amplification was performed as follows: 12 cycles at $94^{\circ} \mathrm{C}$ for $30 \mathrm{~s}, 65^{\circ} \mathrm{C}$ for $30 \mathrm{~s}$ and $72^{\circ} \mathrm{C}$ for $60 \mathrm{~s}$, with annealing temperature lowered by $0.7^{\circ} \mathrm{C}$ every cycle. This was followed by 23 cycles at $94^{\circ} \mathrm{C}$ for $30 \mathrm{~s}, 56^{\circ} \mathrm{C}$ for $30 \mathrm{~s}$ and $72^{\circ} \mathrm{C}$ for $60 \mathrm{~s}$.

\section{Gel analysis}

The reaction products were mixed with equal volumes of formamide loading buffer $(95 \%$ formamide, $10 \mathrm{mmol}^{-1}$ EDTA, bromophenol blue and xylene cyanol), denaturated by incubating at $95^{\circ} \mathrm{C}$ for $5 \mathrm{~min}$ and quickly cooled on ice. The products were analysed on $6 \%$ denaturing polyacrylamide gels. The gel was run at constant power (50-55 W) until the dye was about $2 / 3$ down the length of the gel. AFLP bands were visualized by silver staining.

\section{Data analysis}

For AFLP analysis, bands were scored as 1 denoting presence or 0 denoting absence, and a matrix of AFLP phenotypes was then assembled across all individuals and populations. For each primer, the total number of bands and the polymorphic ones were calculated.

The index of phenotypic diversity $\left(H_{\mathrm{o}}\right)$, the average diversity over all populations $\left(H_{\text {pop }}\right)$ and the mean diversity at species level $\left(H_{\mathrm{sp}}\right)$ were estimated as described by Yeh and Boyle (1997). The component of within-population diversity was estimated as $H_{\mathrm{pop}} / H_{\mathrm{sp}}$, and that of

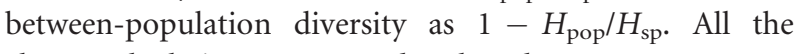
above calculations were undertaken by POPGENE 1.32 (Yeh and Boyle 1997).

A pairwise Euclidean distance matrix was generated with the computer package AMOVA-PREP 1.01 (Miller 1998) and was then used as input for WINAMOva 1.55 for AMOVA analysis (Excoffier et al. 1992) to test whether populations had differing amounts of AFLP variation.

The gene flow (Nm, number of migrants per generation) (Whitlock and McCauley 1999) was approximated as: $N_{\mathrm{m}}=(1 / 4)\left[\left(1 / F_{\mathrm{st}}\right)-1\right]$, where $F_{\mathrm{st}}$ (inbreeding index) values were available from a matrix of pairwise combinations produced by WinAmova.

The Shannon information index $(H)$, which is commonly used to characterize populations' diversity in a community and accounts for both abundance and evenness of the populations that are present. It was calculated using Popgene v1.31 software (Yeh et al. 1999) according to the formula:

$\mathrm{H}=-\sum \mathrm{p}_{i} \ln \mathrm{p}_{i}$ where $\left(\mathrm{p}_{i}\right)$ represents the proportion of a population $i$ relative to the total number of the populations analysed at AFLP markers.

A dendrogram among the populations was constructed with software Darwin (Version 5.0.148) (http:// darwin.cirad.fr/darwin) using the matrix of pairwise $F_{\mathrm{st}}$ values and the unweighted pair-group method with arithmetical averages (UPGMA) (Sneath and Sokal 1973) algorithm.

\section{Acknowledgements}

This investigation was cosponsored by ICARDA and the Ministry of Higher Education and Scientific Research in Tunisia.

\section{References}

Afanasenko, O.S. and Levitin, M.M. (1979) Population structure of causal agent of barley net blotch. Race identification. Mycol Phytopathol 13, 230-234. 
Arabi, M.I.E., Al-Safadi, B. and Charbaji, T. (2003) Pathogenic variation among isolates of Pyrenophora teres, the causal agent of barley net blotch. J Phytopathol 151, 376-382.

Bentata, F., Labhilili, M., El Aissami, A., Bary, S., Yeslem, C.H. and Ibijbijen, J. (2011) Analysis of diversity genetic of Moroccan net blotch populations using amplified fragment length polymorphism (AFLP) markers. Afr J Biotechnol 10, 7548-7554.

Bouajila, A., Abang, M., Haouas, S., Udupa, S., Rezgui, S., Baum, M. and Yahyaoui, A. (2007) Genetic diversity of Rhynchosporium secalis in Tunisia as revealed by pathotype, AFLP, and microsatellite analyses. Mycopathologia 163, 281-294.

Bouajila, A., Zoghlami, N., Al-Ahmed, M., Baum, M., Ghorbel, A. and Nazari, K. (2011) Comparative virulence of Pyrenophora teres $\mathrm{f}$. teres from Syria and Tunisia and screening for resistance sources in barley: implications for breeding. Lett Appl Microbiol 53, 489-502.

Burdon, J.J. and Silk, J. (1997) Sources and patterns of diversity in plant pathogenic fungi. Phytopathology 87, 664-669.

Ceccarelli, S., Grando, S. and van Leur, J.A.G. (1987) Genetic diversity in barley landraces from Syria and Jordan. Euphytica 36, 389-405.

Cromey, M.G. and Parkes, R.A. (2003) Pathogenic variation in Drechslera teres in New Zealand. N Z Plant Prot 56, 251256.

Excoffier, L., Smouse, P.E. and Quattro, J.M. (1992) Analysis of molecular variance inferred from metric distances among DNA haplotypes: application to human mitochondria DNA restriction sites. Genetics 131, 479-491.

Gagkaeva, T.Y. and Yli-Mattila, T. (2004) Genetic diversity of Fusarium graminearum in Europe and Asia. Eur J Plant Pathol 110, 551-562.

Grewal, T.S., Rossnagel, B.G. and Scoles, G.J. (2008) The utility of molecular markers for net blotch resistance across geographic regions. Crop Sci 48, 2321-2333.

Grünwald, N.J., Goodwin, S.B., Milgroom, M.G. and Fry, W.E. (2003) Analysis of genotypic diversity data for populations of microorganisms. Phytopathology 93, 738-746.

Gupta, S. and Loughman, R. (2001) Current virulence of Pyrenophora teres on barley in Western Australia. Plant Dis 85, 960-966.

Harrabi, M. and Kamel, A. (1990) Virulence spectrum to barley in some isolates of Pyrenophora teres from the Mediterranean region. Plant Dis 74, 230-232.

Hovmoller, M.S., Caffier, V., Jalli, M., Andersen, O., Besenhofer, G., Czembor, J.H., Dreiseitl, A., Felsenstein, F. et al. (2000) The European barley powdery mildew virulence survey and disease nursery 1993-1999. Agronomie 20, 729-743.

Jayasena, K.W., Van Burgel, A., Tanaka, K., Majewski, J. and Loughman, R. (2007) Yield reduction in barley in relation to spot-type net blotch. Australas Plant Pathol 36, 429-433.

Jebbouj, R. and El Yousfi, B. (2010) An integrated multivariate approach to net blotch of barley: virulence quantification, pathotyping and a breeding strategy for disease resistance. Eur J Plant Pathol 127, 521-544.

Jonsson, R., Sail, T. and Bryngelsson, T. (2000) Genetic diversity for random amplified polymorphic DNA (RAPD) markers in two Swedish populations of Pyrenophora teres. Can J Plant Pathol 22, 258-264.

Keiper, F.J., Capio, E., Grcic, M. and Wallwork, H. (2007) Development of sequence-tagged microsatellites for the barley net blotch pathogen, Pyrenophora teres. Mol Ecol Notes 7, 664-666.

Khan, T.N. and Tekauz, A. (1982) Occurrence and pathogenicity of Drechslera teres isolates causing spot-type symptoms on barley in Western Australia. Plant Dis 66, 423-425.

Leisova, L., Minarikova, V., Kucera, L. and Ovesna, J. (2005a) AFLP-based PCR markers that differentiate spot and Net forms of Pyrenophora teres. Seed Pathol 54, 66-73.

Leisova, L., Minarikova, V., Kucera, L. and Ovesna, J. (2005b) Genetic Diversity of Pyrenophora teres isolates have detected by AFLP Analysis. Phytopathol J 153, 569-578.

McDonald, B.A. and Linde, C. (2002) Pathogen population genetics, evolutionary potential and durable resistance. Annu Rev Phytopathol 40, 349-379.

McDonald, B.A., Zhan, J. and Burdon, J.J. (1999) Genetic structure of Rhynchosporium secalis in Australia. Phytopathology 89, 639-645.

McLean, M.S., Barbara, J.H. and Hollaway, G.J. (2009) Epidemiology and control of spot form of net blotch (Pyrenophora teres f.sp. maculata) of barley: a review. Crop Past Sci 60, 303-315.

Miller, M.P. (1998) AMOVA-PREP 1.01: a program for the preparation of AMOVA input files from dominantmarkers raw data. Northern Arizona University, Flagstaff, AZ.

Nei, M (1978) Estimation of average heterozygosity and genetic distance from a small number of samples. Genetics 89, 583-90.

Rau, D., Brown, A.H.D. and Brubaker, C. (2003) Population genetic structure of Pyrenophora teres Drechs. The causal agent of Net blotch in Sardinian landraces of barley (Hordeum vulgare L.). Theor Appl Genet 106, 947-959.

Rau, D., Maier, F.J., Papa, R., Brown, A.H.D., Balmas, V., Saba, E., Schaefer, W. and Attene, G. (2005) Isolation and characterization of the mating-type locus of the barley pathogen Pyrenophora teres and frequencies of mating-type idiomorphs within and among fungal populations collected from barley landraces. Genome 48, 855-869.

Serenius, M. (2006) Population Structure of Pyrenophora teres, the Causal Agent of Net Blotch of Barley, PhD Thesis. Finland: MTT Agrifood Research Finland.

Serenius, M., Manninen, O., Wallwork, H. and Williams, K. (2007) Genetic differentiation in Pyrenophora teres populations measured with AFLP markers. Mycol Res 111, 213-223.

Silvar, C., Casas, A.M., Kopahnke, D., Habekub, A., Schweizer, G., Gracia, M.P., Lasa, J.M., Ciudad, F.J. et al. (2009) 
Screening the Spanish Barley Core Collection for disease resistance. Plant Breed 129, 45-52.

Smedegaard-Petersen, V. (1971) Pyrenophora teres f.sp. maculata f.sp. nov. and Pyrenophora teres f.sp. teres on barley in Denmark. Yearbook of the Royal Veterinary and Agricultural University. Copenhagen, Denmark: Royal Veterinary and Agricultural University, pp. 124144.

Sneath, P.H.A. and Sokal, R.R. (1973) Numerical Taxonomy, Freeman, San Francisco.

Steffenson, B.J. and Webster, R.K. (1992) Pathotype diversity of Pyrenophora teres f. teres on barley. Phytopathology 82, 170-177.

Taylor, E.J.A., Konstantinova, P., Leigh, F., Bates, J.A. and Lee, D. (2004) Gypsylike retrotransposons in Pyrenophora: an abundant and informative class of molecular markers. Genome 47, 519-525.

Tekauz, A. (1990) Characterization and distribution of pathogenic variation in Pyrenophora teres $\mathrm{f}$. teres and $P$. teres f. maculata from western Canada. Can J Plant Pathol 12, 141-148.

Trail, F., Xu, H., Loranger, R. and Gadoury, D. (2002) Physiological and environmental aspects of ascospore discharge in Gibberella zeae (anamorph Fusarium graminicearum). Mycologia 94, 181-189.

Vos, P., Hogers, R., Bleeker, M., Reijans, M., Van der Lee, T., Hornes, M., Frijters, A., Pot, J. et al. (1995) AFLP: a new technique for DNA fingerprinting. Nucleic Acids Res 23, $4407-4414$.
Whitlock, M. and McCauley, D.E. (1999) Indirect measures of gene flow and migration: Fst $\neq 1(4 \mathrm{Nm}+1)$. Heredity 82, $117-125$.

Wright, S. (1978) Evolution and the Genetic of Populations Variability Within and Among Natural Populations, Vol. 4. Chicago: University of Chicago Press.

Wu, H.L., Steffenson, B.J., Oleson, A.E. and Zhong, S. (2003) Genetic variation for virulence and RFLP markers in Pyrenophora teres. Can J Plant Pathol 25, 82-90.

Yahyaoui, A.H. (2004) Occurrence of barley leaf blights in Central Western Asia and North Africa. In Meeting the challenges of barley blights. Proc 2nd Intern Workshop on Barley Leaf Blights 7-11 April 2002, ed. Yahyaoui, A.H., Brader, L., Tekauz, A., Wallwork, H. and Steffenson, B. pp. 13-18. Aleppo, Syria: ICARDA.

Yeh, F.C. and Boyle, T.J.B. (1997) Population genetic analysis of co-dominant and dominant markers and quantitative traits. Belg J Bot 129, 157.

Yeh, F.C., Yang, R.C. and Boyle, T. (1999) Popgene version 1.31. Microsoft Window-based Freeware for Population Genetic Analysis. Distributed by F. Yeh. University of Alberta, Edmonton, Canada.

Zaki, K.I. and Al-Masry, A.I.S. (2008) Detection of biochemical genetic markers for net blotch disease resistance and barley grain yield. Egypt J Phytopathol 36, 1-17.

Zoghlami, N., Bouagila, A., Lamine, M., Hajri, H. and Ghorbel, A. (2011) Population genetic structure analysis in endangered Hordeum vulgare landraces from Tunisia: conservation strategies. Afr J Biotechnol 10, 10344-10351. 